Прегледни чланак

Máté Julesz, Ph.D., Scientific Researcher

University of Szeged

Medical Faculty

Insitute for Forensic Medicine

mate.julesz@freemail.hu

\title{
THE CONSTITUTIONAL RIGHT TO HEALTH IN HUNGARY
}

Abstract: In Hungary, the right to health is implied in the Fundamental Law of 2011. The legal history of the constitutional right to health in Hungary dates back to 1949, although this was preceded by an earlier assumption of social human rights. The Hungarian constitutional right to health implies the most important notional elements of the human right to health. One can see that the communist type of constitutional right to health largely differs from the right to health under a democratic rule of law. The Hungarian Constitution of 1949 and the Constitution of the Democratic People's Republic of Korea currently in force reflect a $19^{\text {th }}$-century social human rights conception. In present-day Hungary, there is no room for a similar understanding. Hungary's present constitutional health law is shaped according to the needs of a society within a free market economy.

Keywords: the right to health, constitutional values, human rights, the Hungarian Fundamental Law of 2011, the corpus of the human right to health.

\section{COMPONENTS OF THE RIGHT TO HEALTH}

When one attempts to define the components of the right to health, the first problem is that the human right to health, the constitutional right to health, and the civil law, criminal law and administrative law aspects of the right to health might cover slightly different concepts. First of all, the Hungarian constitutional right to health must be determined because it mostly derives from the human right to health. Secondly, it is clear that civil law, criminal law and administrative law aspects of the right to health have been devised to implement the constitutional right to health within the national legislation of each and every country. Horizontal legal norms must not only be defined on a constitutional level, but there must 
also be horizontal legal norms on the level of civil law as well as on the level of criminal law and administrative law. Sectoral legislation usually follows the horizontal kind, though it is salient that some horizontal regulations are changed without changing sectoral regulations, and not only in Hungary. When it does not run counter to the constitutional right to health (and when the constitutional right to health is not in conflict with the human right to health), changing horizontal health regulations is not necessarily inconsistent with leaving the sectoral health regulations untouched. Both horizontal and sectoral legislation must be in harmony with the Fundamental Law of Hungary. The Hungarian constitutional right to health is not in conflict with the human right to health, so there is no such problem as criminal health law, administrative health law or civil health law being in harmony with the human right to health, but being inconsistent with a constitutional provision on the human right to health. This latter, rather theoretical problem need not be dealt with because the Hungarian Fundamental Law of 2011 implies health norms which respect human rights.

According to André Pieter den Exter, reform was not a political priority in Hungarian healthcare law, particularly in the early 1990s, a situation which he saw as undergoing a rapid shift due to the state of healthcare there (deteriorating morbidity and mortality rates, shocking quality of services, overcapacity of [human] resources, financing problems and spiralling expenditures), which led to radical systemic reforms mainly based on Western ideas of pluralist democracy and marketization; thus, 1995 saw the introduction of a ground-breaking government healthcare reform effort. ${ }^{1}$ I believe that although Article 12(2)(d) of the UN International Covenant on Economic, Social and Cultural Rights (1966) declares that the right of everyone to enjoy the highest attainable standard of physical and mental health must be ensured, inter alia, by steps to be taken by the States Parties to furnish people with medical services and medical attention in the event of sickness, all that does not mean that healthcare services are necessarily free. The human right to healthcare is only part of the human right to health. The human right to health is, axiologically, based on the value of human health. This is an objective value, immanent in human existence. Everyone is entitled to healthcare services, though the standard of these services may vary from country to country. A certain discrepancy is generated by the fact that the value of human health is not put into practice similarly in all countries. This discrepancy causes a human rights problem on a global level. Those living in countries with an insufficient healthcare system suffer a secondary violation of their human right to health. This violation is not necessarily and not in all cases due to a hiatus in the domestic law. Most of all, simple economic factors bring about a violation of the human right to healthcare,

${ }^{1}$ AP den Exter, Healthcare Law-making in Central and Eastern Europe (Intersentia, Antwerpen 2002) 134. 
and no political or civil actor is therefore answerable. Maybe the human right to healthcare expects too much. Maybe the human right to health should not include the human right to healthcare. In the latter case, it would be the task of national legislatures to define how to implement the human right to health. All this brings up the need for deregulation with regard to the human right to healthcare services.

Antal Ádám states that progress in basic rights that protect human life, dignity, justice and welfare was palpable especially after World War II - progress, as Ádám asserts, has come to a halt and should be renewed. ${ }^{2}$ Improvements in medicine necessitate a reshaping of the basic principles of bioethics. Medical progress must be followed by the creation of new constitutional values. The right to health is one of the most developed constitutional rights, not only in Hungary, but all over the world. New constitutional values still arise in relation to the right to health and the constitution-makers have difficulty keeping pace with scientific and bioethical evolution.

It is not merely the Fundamental Law that counts from the perspective of human rights. In Hungary, constitutional rights are mostly included in the text of the Fundamental Law; however, there are theories that accept human rights values that originate from other sources of law and from soft law alike. In Hungary, the Fundamental Law is now the highest source of law. It is disputed whether the Fundamental Law is a simple legislative product, or a special source of law that could not be supervised by the Constitutional Court. The right to health is made explicit by both international law and international soft law. There is an increasing number of international sources of health law. The newly adopted international agreements on health law only become part of the human right to health if they broaden the right to health of the states parties' citizens. These international agreements must be ratified by national parliaments. The increasing number of unratified international agreements on health topics leads to an international soft health law with a heretofore unseen practical effect.

The Hungarian Fundamental Law of 2011 came into force on 1 January 2012. I believe that the human right to health is based on the value of human existence. This value is respected in various ways in various countries. The highest attainable standard of physical and mental health is contained in the adjective 'attainable', meaning that different qualities of healthcare can be attained in different countries. The highest attainable standard of physical and mental health does not cover the same standard even in the EU member states.

The Hungarian Fundamental Law of 2011 mentions the word 'health' six times:

- Article XVII, para. (3): Every employee shall have the right to working conditions which respect his or her health, safety and dignity.

- Article XX, para. (1): Everyone shall have the right to physical and mental health.

2 A Ádám, ‘Észrevételek a magyar alkotmányozáshoz’ (2011) 17/1 Jura 199. 
- Article XX, para. (2): Hungary shall promote the effective application of the right referred to in para. (1) with an agriculture free of genetically modified organisms, by ensuring access to healthy food and drinking water, by ensuring safety in the workplace and the provision of healthcare, by supporting sport and regular physical exercise and by ensuring protection of the environment.

- Article XXI, para. (1): Hungary shall recognise and enforce the right of everyone to a healthy environment.

- Article XXII, para. (3): In order to protect public order, public safety, public health and cultural values, an Act or a local government decree may, with respect to a specific part of public space, provide that residing in a public space as a habitual dwelling shall be illegal.

We can see in the Fundamental Law of Hungary that work health is stressed and precedes food health, sport and the right to a healthy environment, though this latter right is also accentuated. An interesting aspect of the human right to health is expressed in Article XXII, para. (3), which considers vagrancy, considered an infraction in many Western European countries, as an illegal act that violates public health inter alia. Besides this special aspect of the constitutional right to health, all the other aspects are more or less similarly included in Western European constitutions. Vagrancy, which is considered deleterious to Hungarian society, is counterbalanced by the human right to housing in Article XXII, paras. (2) and (3). The human right to housing is only put into practice in the affluent world. From this aspect, the Hungarian Fundamental Law of 2011 has taken a step closer to the human rights situation in the developed world.

It is dogmatically important to differentiate the human right to sport from the human right to regular physical exercise because this differentiation did not figure in the text of the former Hungarian constitution. The Fundamental Law of 2011 underlines that it is not solely the right to regular physical exercise, but also the right to professional and non-professional sporting activities that represent constitutional rights among individuals in Hungary. The right to health is ensured both by regular physical exercise and by sport. The dogmatic difference is postulated by the Hungarian Act on Sport. Sport as a constitutional right is fairly unique in the world of law. Generally, the right to regular physical activity is recognised as a constitutional right, although sport is not a global value, despite the globally acknowledged Olympic spirit. Sport is often centred on competition and financial sponsorship, which are associated with the negative side-effects represented by classical and financial doping. Most countries do not raise sport to the level of human rights. The Hungarian Fundamental Law of 2011 stresses the importance of sport, which might be an allusion to the Hungarian sporting tradition. All in all, this new institution in the Hungarian Fundamental Law is a positive phenomenon, since broadening the scope of human rights by including sport cannot be 
interpreted as a devolution. This is so even if sport is rather a socially inclusive activity than a healthy one. The social inclusion is as an important axiological value as the right of individuals to health; however, social inclusion is somewhat distanced from the human right to health. Otherwise examined, social inclusion can further the right to health, though not directly via the promotion of sport. In the current professional literature, we can read as follows: 'Up until the end of 1990 s, thanks to a process of secondary socialization, doping practices in professional cycling were widespread and largely legitimated by the riders.' 'The prevalence of substance use in sports settings might be under-represented in extant literature.' 'In Sweden, but also internationally, official regimes and public health organizations conduct fairly comprehensive antidoping measures. As a consequence, numerous new ways to learn about and access these types of drugs have emerged. Social media and different internet forums have become part of a new self-help culture in which people can anonymously approach these substances, discuss their experiences of using them and minimize the possibility of encounters with the police. ${ }^{5}$

\section{THE CORPUS OF THE HUMAN RIGHT TO HEALTH}

Antal Ádám conceives of human life and health as values that had existed before they were constitutionalized. ${ }^{6}$ This is undoubtedly right. The right to health can be ensured not solely, but also by positive law. Though, the role of natural law cannot be ignored. ${ }^{7}$ Since positive law can vary from country to country, it is difficult to define a global legal concept of the human right to health. Even if we take natural law into consideration, it would be difficult, though not impossible, to arrive at a global outcome. All that results in a plurality of values which leads to a plurality of national health laws. The true importance is hidden in this plurality because the plurality of values and legal products ensures comparable legislation in different countries. The similar and different traits of national health legislation render the human right to health complex. The value of human health is reflected by this complexity. A human right must be expressed in a way that makes it valid in all legal cultures throughout the world. The specific national regulations must respect the human right to health, which does not mean that all

${ }^{3}$ B Fincoeur et al., 'Communitarian policies in relation to doping markets. The evolution of the distribution of doping products in cycling' (2014) 38 Déviance et Société 3-27.

${ }^{4}$ LA de Grace et al., 'Exploring the role of sport in the development of substance addiction' (2017) 28 Psychology of Sport and Exercise 46-57.

5 J Andreasson et al., 'Online doping. The new self-help culture of ethnopharmacology' (2016) 19 Sport in Society 957-972.

${ }^{6}$ A Ádám, 'Az alkotmányi értékek értelmezéséről' (2010) 16/2 Jura 117.

${ }^{7}$ See also: J Szalma, 'Természetjog és polgári jogi kodifikáció', (2003) 50 Magyar Jog 129-139. 
the details must be very similar. What is above these different national regulatory specificities is the corpus of the human right to health. In my opinion, the true content of the human right to health consists of two levels:

- one is the corpus of the global human right to health that can be defined by applying the lex parsimoniae and by considering the common characteristics of national health laws;

- the other level is the national level of the right to health which includes constitutional types of legal norms as well as special administrative, civil and criminal legal norms.

In most countries, the human right to health is not entirely covered by the national constitution. The administrative healthcare law cannot run counter to the national constitutional regulations, though it is usually allowed to widen the scope of the right to health by parliamentary legislation and governmental regulation. In properly functioning market economies, the lawmakers of the governing party (or parties) are eager to make healthcare services cheaper for citizens than they were before. Making certain healthcare services cheaper than before does not necessarily mean that the level of health of the citizens concerned improves in this way. This rather economic type of legislation is more palpable than any other. In present-day market economies, we may sometimes assist in interventions that curtail a former right to free healthcare services. These negative interventions are neither in the political interests of the governing parties, nor in the interests of the citizens concerned, so making people pay for what was free of charge before usually brings no benefit. In Hungary, this is illustrated by the referendum on the healthcare visit fee in 2008. In the USA, the debate on the withdrawal of Obamacare is also causing political harm to the governing party. In the USA, according to Hall, 'regarding constitutional rights, courts have had limited opportunity to intervene because, outside of specially protected areas such as reproduction, constitutional law gives government wide discretion to define health and safety goals and methods. ${ }^{8}$ In Hungary, we can promote judicial practice that is activist, though mainly in the area of damages and punitive damages in civil liability for health-related injuries, and never overriding constitutional rights.

\section{THE RIGHT TO HEALTH OF NATIONAL AND SEXUAL MINORITIES}

The Preamble to the Constitution of the World Health Organization (1946) declares as follows: 'The enjoyment of the highest attainable standard of health is

\footnotetext{
${ }^{8}$ MA Hall, 'The role of courts in shaping health equity' (2017) 42 Journal of Health Politics, Policy and Law 749-770.
} 
one of the fundamental rights of every human being without distinction of race, religion, political belief, economic or social condition.' According to Article 5(e) (IV) of the International Convention on the Elimination of All Forms of Racial Discrimination (1965), under the auspices of the UN, 'States Parties undertake to prohibit and to eliminate racial discrimination in all its forms and to guarantee the right of everyone, without distinction as to race, colour, or national or ethnic origin, to equality before the law, notably in the enjoyment of, inter alia, the right to public health, medical care, social security and social services.' Negative discrimination against patients in the healthcare system is a current problem not only in developing countries, but also in developed ones with a democratic rule of law. Negative discrimination runs counter to constitutional values in market democracies and is deleterious to legal certainty. In some developing countries, negative discrimination against patients in the healthcare system can be traced back to the lack of appropriate legal regulations. In market democracies, the discrepancy represented by a mostly latent negative discrimination constitutes a system error. This system error could be eliminated by means of greater control by law enforcement and civil society over the provision of healthcare. The problem of minorities' right to health often emerges in post-socialist Eastern European countries. According to Salioska et al., 'Roma in Macedonia suffer from dire health consequences due to economic factors, such as high rates of unemployment and poverty, and social factors, including discrimination by medical providers. Although Macedonia administers a public healthcare system for its citizens, Roma frequently lack access to this system in contravention of the rights to health and equality enshrined in Macedonia's constitution and international law.' ${ }^{\prime 9}$ This kind of anomie in the implementation of the international human right to health is typical not only in Macedonia, but also in Hungary, Romania, Bulgaria and other Eastern European member states of the European Union, which also experience this hiatus in the law.

In Hungary, data on the health status of individuals and on the fact that those concerned belong to a certain minority are sensitive and can thus be collected and published only if permitted by those particular individuals. That is why we cannot gain an insight into the quality of the right to health of the Roma and other minorities. However, in the case of medical research, the practice is more lenient, thus providing some information about the health status of the Roma minority. This source of information suggests that, in Hungary, the quality of the right to health of the Roma minority is as poor as it is in other Eastern European countries. Data protection regulations devised to safeguard the privacy of minorities might conceal minorities' social problems, including problems with access to healthcare.

\footnotetext{
${ }^{9} \mathrm{~N}$ Salioska et al., 'Advancing human rights in patient care of Roma: access to health insurance in Macedonia' (2017) 38 Public Health Reviews, DOI: 10.1186/s40985-017-0064-5.
} 
Another side of the healthcare problem among minorities is negative discrimination against sexual and gender minorities. It is not only national minorities, but also sexual and gender minorities that are unable to exercise their right to health in everyday practice. Negative discrimination against sexual minorities is more common in the developing world than in post-socialist Eastern European countries. According to Muller, 'Although the South African constitution guarantees sexual and gender minority people the right to non-discrimination and the right to access to healthcare, homo- and transphobia in society abound. [...] Sexual orientation and gender identity are important categories of analysis of health equity and lead to disparities. Discriminatory and prejudicial attitudes by healthcare providers, combined with a lack of competency and knowledge are key reasons for these disparities in South Africa. ${ }^{10}$ While national minorities (particularly the Roma minority) still lack the right to health in Eastern European countries, a similar negative discrimination against sexual and gender minorities is little by little vanishing from the Eastern European member states of the Council of Europe. As a result of the application of European law, transsexuals and other sexual minorities do not suffer from significantly more negative discrimination in the healthcare system than majority citizens. This is one of the positive outcomes of the legislative and regulatory measures taken to bring about a congruent system of social rights within Europe.

According to Article 12(1) of the UN Convention on the Elimination of All Forms of Discrimination against Women (1979), 'States Parties shall take all appropriate measures to eliminate discrimination against women in the field of healthcare in order to ensure, on a basis of equality of men and women, access to healthcare services [...]' This UN postulate was put into practice within the European Union and in North America, though there are a great many countries in the world where such sexual discrimination in the application of the domestically constitutionalized right to health represents a real, existing lack of legal certainty. It is thus insufficient to constitutionalize everyone's right to health. This right only becomes a functioning constitutional right when actually applied.

\section{THE RIGHT TO HEALTHY WORKING CONDITIONS}

According to Article 3 of the European Social Charter, revised in 1996, under the auspices of the Council of Europe, 'With a view to ensuring the effective exercise of the right to safe and healthy working conditions, the States Parties undertake to formulate, implement and periodically review a coherent national policy on occupational safety, occupational health and working environment. The

${ }^{10}$ A Muller, 'Scrambling for access: availability, accessibility, acceptability and quality of healthcare for lesbian, gay, bisexual and transgender people in South Africa' (2017) 17 BMC International Health and Human Rights, Article No. 16. 
primary aim of this policy shall be to improve occupational safety and health and to prevent accidents and injury to health arising out of, linked with or occurring in the course of work, particularly by minimizing the causes of hazards inherent in the working environment.' In the Hungarian legal system, work health and safety at work are subdomains of occupational safety and health. Work health includes occupational health and work hygiene. In the Fundamental Law of Hungary, the constitutional right to safety at work and the constitutional right to work health are postulated under Articles XVII and XX alike. Work hygiene and occupational health, the two subdomains of work health, are not mentioned expressis verbis in the Fundamental Law of Hungary, certainly because legislators did not find it important to enter into details regulated at the level of Acts of Parliament. These two rights are derived from the constitutional right to work health, thus leaving no constitutional hiatus. The concept of 'the right to healthy working conditions' stricto sensu covers work hygiene. According to Article XVII, para. (3), of the Hungarian Fundamental Law, 'Every employee shall have the right to working conditions which respect his or her health, safety and dignity.' Thus, the Fundamental Law expands the denotative meaning of 'the right to healthy working conditions' and considers work hygiene as a means to ensure not only work health, but also safety at work and the human right to dignity. This last component, the human right to dignity, is a personal right with various links to the right to health on the level of constitutional personal rights.

EU member states seem to form an élite group within Europe, and not only in the field of social rights. Article 35 of the Charter of Fundamental Rights of the European Union declares as follows: 'Everyone has the right to access to preventive healthcare and the right to benefit from medical treatment under the conditions established by national laws and practices. A high level of human health protection shall be ensured in the definition and implementation of all the Union's policies and activities.' Articles 31 and 32 of the Charter declare everyone's right to healthy working conditions.

It is clear that EU member states are supranationally pushed to legislate on health law and to make healthcare services accessible for their citizens. The Charter does not provide that everyone has the right to healthcare services for free, though the spirit of the Charter urges EU member states not to leave their citizens without appropriate medical care just because they cannot pay for treatment.

In market economies, making all healthcare services free of charge would be counter-productive, so there is no room for such a legal norm in the EU Charter of Fundamental Rights. The Charter leaves it to EU member states to constitutionalize the principle of healthcare services as being free of charge or not. This principle is not considered as a supranational constitutional principle within the EU. Furthermore, there was no totally cost-free healthcare system during the two decades of the social market economy in Hungary (1989-2011). 
As to the right to healthy working conditions, it is rather a matter of economic human rights than one of social human rights. This human right is that of the employees, and to be employed is an economic question, not a social one. However, the right to healthy working conditions is a human right of a dual character:

- it has an economic purport and

- it also has a certain social purport.

The economic purport is that holders of financial capital are only allowed to employ persons without financial capital sufficient to live on if they can offer them working conditions which do not infringe on their right to health. The social purport is that employees' right to health is equal to the right to health of all individuals, including those who are not employed because (a) they have sufficient financial capital to live on, (b) they are already retired or (c) they cannot be employed for any other reason.

A need for legal protection of the employed dates back to ancient times. The quality of healthy working conditions was, for centuries, not an important factor in the economic functioning of the state. Healthy working conditions as a human right only emerged in the $19^{\text {th }}$ century, and, in most countries in the developing world as well as in some countries in the so-called developed world, this human right is still lacking because the economic functioning of the state predominates over respect for social human rights. Unhealthy working conditions can be detected in some Eastern European countries. Absent social and economic ethics, solely positive law is not sufficient to ensure healthy working conditions. The lack of a proper ethical approach among employers hinders the proper functioning of the law. All that cannot be blamed on the rules of the market economy. The market economy malfunctions in countries where social rights, such as the right to healthy working conditions, suffer from an axiological deficit. A constitutionalized human right must be respected by all actors in a market economy. No economic actor is legally allowed to disregard any constitutional value. For example, Section 35 of the Washington State Constitution declares that 'the legislature shall pass necessary laws for the protection of persons working in mines, factories and other employments dangerous to life or deleterious to health'. The word 'health' occurs ten times in that constitution.

The human right to health correlates with the human right to life. In the USA, according to Hood, there was 'a shift in the nature of professional expertise dominating the federal bureaucracy during the 1970s and 1980s, as changing conceptions of health and safety regulation during this period gave academic economists the opportunity to make new claims about the exclusive authority of microeconomic theory for understanding the economic value of life in federal planning. [...] Pricing human life results not only from the renegotiation of moral boundaries around the economic logic of the market, but also from the reorgani- 
zation of expert authority and the consolidation of scientific expertise around both the meaning and the measurement of value.'11

According to Article 11(1)(f) of the UN Convention on the Elimination of All Forms of Discrimination against Women (1979), 'States Parties shall ensure, on a basis of equality of men and women, the same rights, in particular, inter alia, the right to protection of health and to safety in working conditions, including the safeguarding of the function of reproduction.' This topic seems to be a historical one in the European Union and in North America, though the hiatus of it is an extant source of social injustice in many developing countries and it erodes the human right to healthy working conditions, even if, in theory, this right is domestically constitutionalized.

\section{THE RIGHT TO A HEALTHY ENVIRONMENT}

Integration of European health law has long been more visible in EU member states than in other European states. This phenomenon is due to European Union legislation, which is (not only) socially more sensitive and more integrative than that of other European international organizations. However, in 2006, in the case of Marangopoulos Foundation for Human Rights $v$ Greece, the European Committee of Social Rights explicitly recognised the 'right to a healthy environment' as embodied in the right to health under the European Convention on Human Rights. ${ }^{12}$ Similarly, according to Cohen, 'Amending the Washington State Constitution to include a positive right to a healthy environment would not be a radical departure from current policy. ${ }^{13}$ There is an apparent hiatus in the law of some economically developed and legally democratic states. Globally, it is still questionable whether the right to a healthy environment really should be constitutionalized or if it is unnecessary. ${ }^{14}$ Natural law may suffice without legislation; however, positive law is indisputably a sure way to provide legal certainty.

Article XX of the Fundamental Law of Hungary asserts that the protection of the environment is a constitutional value that promotes everyone's right to physi-

${ }^{11} \mathrm{~K}$ Hood, 'The science of value: economic expertise and the valuation of human life in US federal regulatory agencies' (2017) 47 Social Studies of Science 441-465.

${ }^{12}$ M Trilsch, 'European Committee of Social Rights: the right to a healthy environment' (2009) 7 International Journal of Constitutional Law 530.

${ }^{13}$ DR Cohen, 'Forever evergreen: amending the Washington State Constitution for a healthy environment' (2015) 90 Washington Law Review 349-404.

${ }^{14}$ On the right to a healthy environment and sustainable development in the Republic of Serbia: D. Popov, Načela zaštite životne sredine u dokumentima Ujedinjenih nacija, Evropske unije i Zakona o zaštiti životne sredine Republike Srbije, Zbornik radova Pravnog fakulteta u Novom Sadu, 2/2013, 139-145. 
cal and mental health. ${ }^{15}$ The role of environmental protection is also stressed in Article XXI, which postulates everyone's right to a healthy environment. The constitutional right to a healthy environment is based on the value of human health. This value is specified in the Hungarian Act on Health. In contrast, protection of the environment, which also promotes human health, is specified within the Hungarian Act on Environmental Protection. The difference can be explained with the dogmatic approach. The protection of the environment puts an accent on the environment, which is an objective value. All people should respect this objective value to preserve the environment for future generations. The value of a healthy environment is a subjective value with a content that varies from one individual to another. A healthy environment does not necessarily mean the same for all individuals. For example, a person with asthma needs an environment that differs from that of an otherwise healthy person. The concept of a healthy environment may contain various semantic elements, thus making the value of a healthy environment a subjective value. However, this value is represented by everyone's constitutional right to a healthy environment. This means that the Hungarian state ensures a healthy environment for all, even if this constitutional norm might place a serious burden on the state of Hungary. This is theoretically good, but might result in situations in which the state cannot fulfil its task to provide a healthy environment.

The protection of environmental elements is an objective value, though it is not restricted to the human environment: natural values, such as animal rights, nature conservation and the protection of flora are also parts of the protection of environmental elements. The protection of the built environment is solely in the interests of human beings. The protection of the natural environment is partly in the interests of human beings and partly in the interests of the flora and fauna. All that is regarded from the aspect of human rights, which means that the protection of the environment is an objective human value. From a human rights perspective, this is correct; however, it seems to be incorrect from an environmentalist viewpoint. One does not have to be an eco-anarchist to accept that, besides human rights, animals and plants should also be protected by law. The wording of the Hungarian Fundamental Law considers the human right to a healthy environment as a constitutional value, while the flora and fauna enjoy an indirect constitutional protection (under Article P). All this derives from the legal standpoint that plants and animals are not persons. It is true that the new Hungarian Civil Code as well as the Austrian, German and Swiss Civil Codes declare that animals are not simply chattel. The Criminal Codes of these countries furnish animals with legal protection against torture. Although animals are understood

${ }^{15}$ See also: J Szalma, 'Magyarország Alaptörvényéröl', (2011) 58 Magyar Jog 641-650. See also: G Horváth, 'The renewed constitutional level of environmental law in Hungary', (2015) 56 Acta Juridica Hungarica, 302-316. See also: A Dudás, 'Nacela politike zastite zivotne sredine u pravu Evropske unije', (2013) 47 Zbornik Radova Pravni Fakultet (Novi Sad) 377-390. 
to be sensitive living beings in the law of most developed countries, the law provides that animals are mere objects with constitutional protection. Hungarian constitutional law does not regard animals as sensitive living beings, thus falling behind the Hungarian civil law and criminal law. This reluctance in Hungarian constitutional law seems inexplicable and leaves a dogmatic lacuna in Hungarian law. This phenomenon highlights the fact that it is social and scientific development that pushes forward legal development rather than the inverse.

Nowadays, such legal disputes as those between tobacco companies and states with national anti-tobacco legislation invoke economic considerations of the social human right to health. In many countries, tobacco companies tend to dispute national anti-tobacco legislation sub judice. The countries concerned attempt to develop the reasoning that all those legislative products promote the international human right to health, as well as the national constitutional right to health. ${ }^{16}$ The observation must be made that tobacco companies mostly wish to protect their economic interests and that the social right to health is becoming deteriorated by the overwhelming economic interests of those companies and by the domestic legislation that endeavours to ensure a free market economy.

\section{THE CORRELATION OF THE RIGHT TO HEALTH WITH THE RIGHT TO DIE}

The right to life and the right to human dignity are interrelated. The question arises whether the human right to health is also related to the right to human dignity. According to the major current European judicial interpretation, there is always dignity in human life - whether healthy or unhealthy. I believe that that there is less dignity in impaired human health. When it comes to a life with damaged health, one might speak of a life without dignity. In those countries, where the active form of euthanasia or at least the institution of physician-assisted suicide is legal, if a person with impaired health arrives at a life without dignity, this person is allowed to put an end to their life. ${ }^{17}$ The legal preconditions to exercise the right to die are determined by law. ${ }^{18}$ In Europe and America, this right is assigned to citizens of an increasing number of states. This legislative tendency shows that not all human lives are marked by human dignity, but only those which are associated with a 'healthy' character. It would be a slippery slope

${ }^{16}$ EU Petersmann, 'How to reconcile health law and economic law with human rights? Administration of justice in tobacco control disputes' (2015) 10 Asian Journal of WTO \& International Health Law and Policy 27-28.

${ }^{17}$ M Julesz, 'Active euthanasia, or assisted suicide?' (2016) 157 Orvosi Hetilap 1595-1600.

${ }^{18}$ More on ethical dillemas tied to euthanasia: D. Simović, B. Simeunović-Patić, Eutanasija i etičke dileme - ljudsko dostojanstvo naspram svetosti života, Zbornik radova Pravnog fakulteta u Novom Sadu, 2/2017, 317-336. 
to assert that all unhealthy lives lack dignity. According to the Hungarian Fundamental Law, two interpretations may arise:

- one is that persons who live an unhealthy life should be allowed to enjoy at least physician-assisted suicide as a healthcare service covered by social security;

- the other is that no sick person may be aided in engaging in an act of suicide and no physician is allowed to engage in an act of killing a patient.

Since the Fundamental Law of Hungary neither explicitly recognises the right to die as a constitutional right, nor does it prohibit it, Hungarian constitutional law does not consider it as a constitutional value. The lack of an expressis verbis prohibition of the right to die leaves room for future legalisation (i.e. the right to active euthanasia or physician-assisted suicide). The global human right to health does not necessarily imply the right to die when the health of an individual is impaired to the point of lacking dignity. National legislators are free to grant citizens the right to die or not. In most countries in Europe and North America, the institution of passive euthanasia is legal. This is a first step toward legalising all forms of the right to die. If we take the USA, for example, it has been a long journey to the current legalisation of physician-assisted suicide there - and this only applies in six American states and in Washington DC. ${ }^{19}$ It seems difficult to accept that an unhealthy life may lack dignity for certain citizens and that it is not unconstitutional to allow those citizens to opt for the right to die. According to Ganzini, 'Concerns that legalisation would undermine the development of palliative care and be disproportionately utilised by patients unable to access good end of life care have been unfounded. ${ }^{20}$ According to Quill, 'Palliative care and hospice should be the standards of care for all terminally ill patients. The first place for clinicians to go when responding to a request for assisted death is to ensure the adequacy of palliative interventions. Although such interventions are generally effective, a small percentage of patients will suffer intolerably despite receiving state-of-the-art palliative care, and a few of these patients will request a physician-assisted death. ${ }^{.21}$ According to Stronegger et al., 'In most European countries, the attitudes regarding the acceptability of active euthanasia have clearly changed in the population since World War II. [...] Ethical convictions of medical doctors seem to fall back behind a higher valuation of the autonomy of the patient. ${ }^{, 2}$

The danger of the slippery slope emerges when mentally ill persons are allowed to opt for active euthanasia or physician-assisted suicide. This slippery slope can be avoided if the right to active euthanasia or physician-assisted suicide

${ }^{19}$ M Julesz, 'Active euthanasia in Colombia and assisted suicide in California' (2016) 157 Orvosi Hetilap 174-179.

${ }^{20}$ L Ganzini, 'Legalised physician-assisted death in Oregon' (2016) 16 QUT Law Review 76-83.

${ }^{21}$ TE Quill, 'Physicians should assist in suicide when it is appropriate' (2012) 40 Journal of Law, Medicine and Ethics 57-65.

${ }^{22}$ WJ Stronegger et al., 'Changing attitudes towards euthanasia among medical students in Austria' (2011) 37 Journal of Medical Ethics 227-229. 
is only granted to those mentally ill persons with legal capacity. For example, chronic depression does not necessarily make the patient legally incapable, though it certainly causes unbearable suffering. All this reasoning is based on legal dogmatics, which defines the right to health as the right to physical and mental health. The right to mental health can also be related to the right to die, though a much more attentive examination of each and every case is necessitated than in the case of impaired physical health.

The right to health and the right to die are clearly related to each other. The strength of this relationship depends on the particular position held by legal scholars. One may state that this relationship is weakened by religious or ethical aspects. Others may assert that the plurality of religious and ethical values brings about a fairly strong relationship between the right to health and the right to die. Without bias, I can accept both the theory of a strong correlation, fortified by religious indulgence and permissive ethics, and the theory of a weak correlation. It is the task of national legislators to decide which theory to opt for. At any rate, a legislative product that legalises the right to die must be constitutionally well-founded. It is not sufficient to declare that the right to die is not unconstitutional.

In the Hungarian legal system, the right to health is ensured by the state and it is also an obligation of each and every citizen to protect their own and each other's health (Act on Health, Section 5); however, there is merely a weak correlation between the right to health and the right to die. This weak correlation is represented by the right to passive euthanasia. The legal institution of passive euthanasia dates back two decades in Hungary. It is still a long road to the legalisation of active euthanasia and physician-assisted suicide. In 2003, a member of the Hungarian Constitutional Court issued an opinion to the effect that it is not the task of the Constitutional Court to decide on the legalisation of the right to die and that this legal institution is not unconditionally unconstitutional (Parallel opinion issued by András Holló, Judgment of 28 April 2003 of the Constitutional Court of Hungary, No. 22/2003).

I believe that in Hungary, if we look far into the future, a possible legalisation of active euthanasia and physician-assisted suicide should be preceded by an amendment to the Fundamental Law. This is my opinion, even if in practice it means that the right to die cannot be expanded soon. The constitutional right to health may be interpreted in many ways, except for curtailing citizens' existing liberties. The institutions of active euthanasia and physician-assisted suicide would not curtail citizens' liberties; however, tangible religious and ethical objections necessitate the precise drafting of an amendment to the Fundamental Law of Hungary before launching a legislative process.

According to Biggs, 'In England and Wales, assisted suicide remains prohibited by the Suicide Act 1961, as amended by the Coroners and Justice Act 2009, Section 59, and euthanasia is regarded as homicide under common law. The Suicide Act 1961 was introduced largely to abrogate the rule of law whereby it is a 
crime to commit suicide (Suicide Act 1961, Section 1). Prior to that, suicide was regarded as self-murder and a person who attempted suicide could be prosecuted. ${ }^{23}$ The decriminalization of suicide was a huge step toward widening the right to self-determination of sick persons, not only in England and Wales, but also in Hungary and in other countries with appropriate legislation. The right to suicide among sick persons still does not encompass aiding patients in the act of suicide. An unhealthy life may be a valuable life. Should patients really obtain the right to commit suicide? In England and Wales, as well as in Hungary, the answer is yes. Should patients receive assistance in the act of suicide? In England and Wales, as well as in Hungary, the answer of the legislators is at present no. Could this answer be changed? The response is an uncertain yes because suicide and assisted suicide should not be the primary reactions of patients to the prospect of an unhealthy life, even if this life involves suffering and the end of life is near. In the Preamble to the Constitution of the World Health Organization (1946), we read that 'health is a state of complete physical, mental and social well-being and not merely the absence of disease or infirmity'. This assertion might theoretically serve to enlarge the right to die to include cases in which lack of good health is based not on a physical or mental illness, but rather on a very low standard of living. I believe that this theory should not be used to legalise any form of the right to die. Low socio-economic well-being should not serve as a reason to legalise euthanasia or assisted suicide.

\section{PLAY ON WORDS AND UNCONSTITUTIONAL REALITY}

The right to health is a constitutional right not only in developed democracies, but also in countries such as North Korea. Article 57 of that country's Constitution declares the people's constitutional right to a hygienic environment and working conditions. Article 43 declares that 'the state shall put the principles of socialist education into practice and raise the new generation to be [...] morally sound and physically healthy'. Article 56 declares that 'the state shall consolidate and develop the system of universal free medical service, and consolidates the district doctor system and the system of preventive medicine to protect people's life and improve working people's health'. These postulates recall the era of 1950s Hungary. The right to health was a constitutional right according to Article 47 of the country's Constitution of 1949: 'The People's Republic of Hungary protects the working people's health and takes care of the unemployed. The People's Republic of Hungary ensures this protection by organizing social security and by providing healthcare.'

${ }^{23} \mathrm{H}$ Biggs, 'From dispassionate law to compassionate outcomes in healthcare law, or not' (2017) 13 International Journal of Law in Context 179. 
This resemblance between the text of North Korea's Constitution in effect and that of the Constitution of the People's Republic of Hungary is due to the historical fact that communism was theoretically built on the legitimating power of the working people. Like that of communist North Korea today, the first aim of communist Hungary was to protect 'the health of the working people'. This is a human rights conception taken from the late $19^{\text {th }}$ century. The other side of the coin is that the historical facts show that the health of working people was fairly poor in communist Hungary, just as it is in communist North Korea today. Thus, the mere declaration of the protection of working people's health does not result in a properly functioning healthcare system; in fact, working people's health remains below globally accepted standards in the latter country. Also, theoretically, one might assert that the highest attainable level of health in a particular country relates to that very country, and, thus, the Democratic People's Republic of Korea fulfils its constitutional task to ensure a healthcare system which can be locally attained as a maximum. This is, of course, a play on words. The historical perspective makes it clear for the reader that a precisely worded Constitution is insufficient to ensure human rights in practice. According to the Preamble to the Constitution of the World Health Organization (1946), 'Unequal development in different countries in the promotion of health and control of disease, especially communicable disease, is a common danger.' According to Article II of the WHO Declaration of Alma-Ata (1978), 'The existing gross inequality in health status of the people particularly between developed and developing countries as well as within countries is politically, socially and economically unacceptable and is, therefore, of common concern to all countries.' From the aspect of the history of the human right to health, Article $\mathrm{V}$ of this declaration is, by and large, of outstanding relevance: 'Governments have a responsibility for the health of their people which can be fulfilled only by the provision of adequate health and social measures. The main social target of governments, international organizations and the whole world community in the coming decades should be the attainment by all peoples of the world by the year 2000 of a level of health that will permit them to lead a socially and economically productive life.'

The right to health was not a human right before the emergence of the principle of democratic equality. 'Working people' could not purchase good healthcare services, so they became useless to employers as well as to the state when they fell ill. In the $19^{\text {th }}$ and $20^{\text {th }}$ centuries, this was one of the screaming injustices to be eradicated. There are examples in legal history of trials that attempted to put a halt to this source of inequality. One cannot predict whether the human right to health will ever be put into practice throughout the world. Indeed, the evolution of the right to health is correlated with the axiological development of each and every country. Thus, the quality of the right to health is highly dependent on the ruling political system, not to mention economic resources. 
Др Мат̄е Јулес, научни истираживач

Универзитетеи у Сегеедину

Медицински факулиетеи

Инстиит̄ичй за судску медицину

mate.julesz@freemail.hu

\section{Уставно право на здравље у Мађарској}

Сажейак: У Мађарској, ирраво на здравље ирреййосйављено је Основним законом из 2011. гоодине. Правна истиорија устиавног йрава на здравље у Мађарској дайира из 1949. гоодине, иако је йоме йрейходила ранија йреййостиавка о сочијалним људским ирравима. Мађарско устиавно ираво на здравље иретийостивљь најважније номиналне елемение људског̄ ирава на здравље. Може се ириметиитии да се комунистиччки тиии устиавног̄ иррава на здравље у великој мери разликује од ирава на здравље унуйар демокрайке владавине йрава. Мађарски устиав из 1949. гоодие и Усйав Демокрайске Рейублике

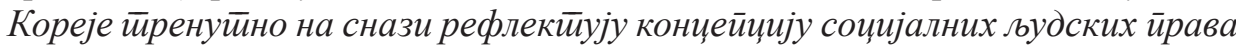
деветинаесииог века. У Мађарској данас нема иростиора за слично разумеваюе. Садащње мађарско устиавно ирраво на здравље је обликовано иррема йойребама друщиива у оквиру слободне ирюжищне економије.

Кључне речи: ирраво на здравље, устиавне вредностии, људска иррава, Мађарски Основни закон из 2011. гоодие, корӣус људског̄ ирава на здравље.

Датум пријема рада: 09.12.2017. 